\title{
EFFICACY OF OXAMNIQUINE, PRAZIOUANTEL AND A COMBINATION OF BOTH DRUGS IN SCHISTOSOMIASIS MANSONI IN BRAZIL
}

\author{
K. ZWINGENBERGER (1), J. A. NOGUEIRA QUEIROZ (2), U. POGGENSEE (1), J. E. ALENCAR (2), \\ J. VALDEGUNAS (3), F. ESMERALDA (3) \& H. FELDMEIER (1)
}

\begin{abstract}
A randomized clinical trial was carried out to compare the efficacy of a low-dosage combination of oxamniquine $(7.5 \mathrm{mg} / \mathrm{kg})$ plus praziquantel $(20 \mathrm{mg} / \mathrm{kg})$ against either agent, oxamniquine $(15 \mathrm{mg} / \mathrm{kg})$ or praziquantel $(40 \mathrm{mg} / \mathrm{kg})$ alone, in the treatment of schistosomiasis mansoni in the Brazilian north-east.

The drugs were randomly administered per os to 91 patients. Six and twelve months after treatment $89 \%$ of those admitted to the trial were reexamined by Kato-Katz method (ten slides) and MIF technique (one gram of stool)

The achieved cure rates, as defined by absence of $\mathbf{S}$. mansoni eggs in the faeces of individual patients at all points during the parasitological follow-up, were $81.8 \%$, $81.2 \%$ and $67.6 \%$ for praziquantel, oxamniquine and the combination respectively. The reduction of eggs excretion in non-cured patients six months after therapy ranged from 93.8-96.8\% with praziquantel, 32.5-97\% with oxamniquine and 76.9-99.5\% with the combination.

It is concluded that, at the used dosages, the three therapeutical regimens give similar and satisfactory results in the treatment of uncomplicated S. mansoni infection in Brazil.
\end{abstract}

KEY-WORDS: Schistosoma mansoni; Oxamniquine; Oxamniquine resistance; Praziquantel.

\section{I $\mathbf{N}$ T R $\quad$ O D D U C T T I O N}

Two compounds are currently recommended for the treatment of schistosomiasis manso$\mathrm{ni}^{\mathrm{5} 2}$. Oxamniquine has been used in large scale mass treatment in Brazil, in an attempt to curtail the transmission of this helminthiasis and to achieve eradication ${ }^{30,45,48.51}$. The drug was advantageous from the point of view of cost-effectiviness, since satisfying cure rates have been ac- complished in this country with a single oral do-: se of $15 \mathrm{mg} / \mathrm{kg}$ body weight $\mathrm{t}^{33,40}$. In contrast, doses up to $60 \mathrm{mg} / \mathrm{kg}$ are required in Africa to attain similar therapeutical efficacy in schistosomiasis mansoni ${ }^{39}$. Oxamniquine is usually well tolerated $^{35,42}$ and clinical improvement has been observed in advanced cases of this parasitosis ${ }^{3.23}$. Nevertheless serious central nervous adverse 
ZWINGENBERGER, K.: NOGUEIRA QUEIROZ, J. A.: POGGENSEE. U.: ALENCAR, J. E.: VALDEGUNAS, J.; ESMERALDA. F. \& FELDMEIER, H. - Efficacy of oxamniquine, praziquantel and a combination of both drugs in schistosomiasis mansoni in Brazil. Rev. Inst. Med. trop. São Paulo, 29:305-311, 1987.

reactions have been reported following its administration ${ }^{5}$ 16. 36. 37.47 . Unfortunately it also became apparent aiready at early stages of the eradication campaign in Brazil that $\mathbf{S}$. mansoni strains resistant to oxamniquine exist ${ }^{32}$. Such resistance has been confirmed by other investigators $^{2}$ 18, 28, 41 .

Praziquantel is a novel antihelminthic agent active against all schistosome species pathogenic to $\operatorname{man}^{1,26,49}$ as well as a variety of other human trematode ${ }^{50}$ and cestode ${ }^{27}$ infections. It proved to be a safe drug ${ }^{24,}{ }^{25,}{ }^{38}$ which has been administered to schistosomiasis patients with hepatosplenomegaly without inducing any severe untoward effects ${ }^{11}{ }^{13}$. Moreover, it has been successfully used in oxamniquine-resistant cases of schistosomiasis mansoni ${ }^{4,9.20}$.

Recently it has been suggested that the combination of oxamniquine and praziquantel, even at low dosages, produces a synergistic action against S. mansoni ${ }^{8,18,28.44}$. These preliminary findings have not yet been clinically investigated in northeastern Brazil: Thus we have carried out a field trial at this endemical region in order to compare the efficacy of a half-dose combination on these two drugs against each one alone.

\section{PATIENTS AND METHODS}

A total of 93 subjects living at an area endemic for schistosomiasis in the municipality of Crato, situated in the interior of Ceara state, Brazil, were diagnosed as infected by $\mathbf{S}$. mansoni in a parasitological survey. All of them, 70 males and 23 females, presented the uncomplicated form of the disease. The median age was 21 ranging from 10 to 62 years. Only $20 \%$ were younger than 16 or older than 30 years. Two females allocated to the praziquantel group were exempted from treatment at the beginning of the study because of pregnancy. They received therapy post-partum but were excluded from the evaluation.

Tne worm burden was quantified on the basis of faecal egg counts using the Kato thick smear technique as modified by KATZ et al. ${ }^{31}$.
The number of eggs per gram of faeces prior to treatment was calculated from five slides (equivalent to $210 \mathrm{mg}$ of stool). Parasitological followup examinations performed on a single specimen obtained three, six and twelve months posttreatment, comprised a minimum of ten slides (corresponding to $420 \mathrm{mg}$ of stool) per patient. In addition, approximately $1 \mathrm{~g}$ of stool sample was examined by the merthiolate-formol (Mrif) concentration technique ${ }^{6}$. This methodology was based on the rationale that a single Kato thick smear reliably indicates the intensity of infection only if egg excretion is higher than 50 ova per gram of faeces, whereas below this level false-negative results are frequent $t^{46}$.

Subjects with previous history of seizures were excluded from the trial. The patients were then randomly allocated to.one of the following treatment group: (a) oxamniquine $15 \mathrm{mg} / \mathrm{kg}$ in a single dose; (b) praziquantel $40 \mathrm{mg} / \mathrm{kg}$ in two split doses, taken 4 hours apart; and (c) a combination of oxamniquine $7.5 \mathrm{mg} / \mathrm{kg}$ plus praziquantel 20 $\mathrm{mg} / \mathrm{kg}$, taken simultaneously. Tablets of both drugs were used in adults; in children, oxamniquine was administered in the form of syrup. Thirty-two individuals were treated with oxamniquine, 24 with praziquantel and 35 received the combination. The unequal number of patients within the three groups was due to the non-prefixed limitation in the amount of cases entering the trial. In such event it may occur that at a certain moment the open random allocation brings about a disproportional distribution of patients amongst groups.

The main characteristics of the patients enrolled in the three groups are shown in Table 1. They did not differ in age or sex composition, and there was no significant difference in pretreatment worm burden. The overall median number of eggs per gram of stool prior to therapy was 168, range 42-964. Fewer than 100 eggs per gram were encountered in $27 \%$ of the individuals, whereas in $26 \%$, egg excretion exceeded 300 per gram.

Statistical evaluation was performed according to Fisher's exact test for comparison of relative frequencies, and Mann-Whitney signed-rank test to compare reductions in egg excretion. 
ZWINGENBERGER, K,; NOGUEIRA QUEIROZ, J. A.; POGGENSEE, U.; ALENCAR. J. E.: VALDEGUNAS, J.; ESMERALDA. F. \& FELDMEIER, H. - Efficacy of oxamniquine, praziquantel and a combination of both drugs in schistosomiasis mansoni in Brazil. Rev. Inst. Med. trop. São Paulo, 29:305-311, 1987.

\section{TABLE I}

Characteristics of the patients within the three drug groups $(\mathrm{OXM}=$ oxamniquine, $P Z Q=$ praziquantel, $\mathrm{EPG}=$ number of $\mathbf{S}$. mansoni eggs per gram of faeces।

\begin{tabular}{|c|c|c|c|c|}
\hline \multicolumn{2}{|c|}{ Drug groups } & Praziquantel & Oxamniquine & OXM \& PZQ \\
\hline \multicolumn{2}{|c|}{ Dosages (mg/kg) } & $40^{\circ}$ & 15 & $7.5+20$ \\
\hline \multicolumn{2}{|c|}{ Treated cases } & 24 & 32 & 35 \\
\hline Sex & Male/female & $16 / 8$ & $25 / 7$ & $29 / 6$ \\
\hline Age & $\begin{array}{l}\text { Median } \\
\text { Range } \\
<16 \text { ys. } \\
16-30 \text { ys. } \\
>30 \text { ys. }\end{array}$ & $\begin{array}{c}22 \text { ys. } \\
12 \div 50 \text { ys. } \\
22 \% \\
56 \% \\
22 \%\end{array}$ & $\begin{array}{c}21 \text { ys. } \\
10.62 \text { ys. } \\
21 \% \\
61 \% \\
18 \%\end{array}$ & $\begin{array}{c}20 \text { ys. } \\
12-54 \text { ys. } \\
18 \% \\
61 \% \\
21 \%\end{array}$ \\
\hline $\begin{array}{l}\text { Worm } \\
\text { burden }\end{array}$ & $\begin{array}{l}\text { Median } \\
\text { Limits }^{* *} \\
<-100 \mathrm{EPG} \\
100-300 \mathrm{EPG} \\
\quad>300 \mathrm{EPG}\end{array}$ & $\begin{array}{c}132 \mathrm{EPG} \\
100-216 \mathrm{EPG} \\
32 \% \\
45 \% \\
23 \%\end{array}$ & $\begin{array}{c}156 \mathrm{EPG} \\
132-236 \mathrm{EPG} \\
28 \% \\
44 \% \\
28 \%\end{array}$ & $\begin{array}{c}176 \mathrm{EPG} \\
120-216 \mathrm{EPG} \\
25 \% \\
50 \% \\
25 \%\end{array}$ \\
\hline
\end{tabular}

* Twice $20 \mathrm{mg}$, four hours apart.

* $95 \%$ confidence interval.

\section{RESULTS}

Clinical tolerability to all three medications was uneventfull as no difference was noticed in regard to the usual side-effects already reported in Brazil with praziquantel, oxamniquine, and inclusively with the combination ${ }^{\mathrm{t} 0}, 15,21$.
Table II shows the number of examined pa tients, positive cases and eggs excreted per gram of faeces at different points of the follow-up period. Seventy-two percent, $89 \%$ and $89 \%$ respectively, of the treated patients could be reexamined three, six and twelve months after theraphy. The cure rates, i. e., failure to detect ova

\section{TABLE II}

Parasitological findings 3, 6 and 12 months after treatment (for negative stool samples by Kato-Katz but positive by MIF concentration, an EPG of 5 was assumed in order to calculate the reduetion in ova excretion)

\begin{tabular}{|c|c|c|c|c|}
\hline \multirow{2}{*}{$\begin{array}{c}\text { Follow-up } \\
\text { Controls }\end{array}$} & \multirow{2}{*}{ Findings } & \multicolumn{3}{|c|}{ Dose groups } \\
\hline & & Praziquantel & Oxamniquine & OXM \& PZQ \\
\hline $\begin{array}{l}\text { 3rd. } \\
\text { Month }\end{array}$ & $\begin{array}{l}\text { Examined patients* } \\
\text { Positive cases }{ }^{* *} \\
\text { EPG in non-cured cases - range } \\
\text { Reduction of EPG - range }\end{array}$ & $\begin{array}{l}18(71 \%) \\
0\end{array}$ & $\begin{array}{c}26(81 \%) \\
2(8 \%) \\
24-186 \\
46.1-67.6 \%\end{array}$ & $\begin{array}{l}21(61 \%) \\
1(5 \%) \\
48 \\
87.7 \%\end{array}$ \\
\hline $\begin{array}{l}\text { 6th } \\
\text { Month }\end{array}$ & $\begin{array}{l}\text { Examined patients* } \\
\text { Positive cases** } \\
\text { EPG in non-cured cases - range } \\
\text { Reduction of EPG - range }\end{array}$ & $\begin{array}{c}20(83 \%) \\
3(15 \%) \\
5-10 \\
93.8-96.8 \%\end{array}$ & $\begin{array}{r}30(94 \%) \\
6(20 \%) \\
5-230 \\
32.5-97.0 \%\end{array}$ & $\begin{array}{c}32(91 \%) \\
8(25 \%) \\
5-25 \\
76.9-99.5 \%\end{array}$ \\
\hline $\begin{array}{l}12 \text { th. } \\
\text { Month }\end{array}$ & $\begin{array}{l}\text { Examined patients* } \\
\text { Positive cases** } \\
\text { EPG in non-cured cases - range } \\
\text { Reduction of EPG - range }\end{array}$ & $\begin{array}{c}22(92 \%) \\
2(9 \%) \\
5-85 \\
39.2-96.9 \%\end{array}$ & $\begin{array}{c}30(94 \%) \\
4(13 \%) \\
10-25 \\
72.2-94.0 \%\end{array}$ & $\begin{array}{c}28(80 \%) \\
4(14 \%) \\
15-25 \\
82.5-93.7 \%\end{array}$ \\
\hline
\end{tabular}

\footnotetext{
* In brackets, the percentage of reexamined cases in relation to treated patients.
}

** In brackets the percentage of positive cases in relation to reexamined patients. 
ZWINGENBERGER, K.; NOGUEIRA QUETROZ, J. A.; POGGENSEE, U.; ALENCAR, J. E.: VALDEGUNAS, J.; ESMERALDA F. \& FELDMEIER, H. - Efficacy of oxamniquine, praziquantel and a combination of both drugs in schistosomiasis mansoni in Brazil. Rev. Inst. Med. trop. São Paulo, 29:305-311, 1987

in the faeces, corresponding to these control in tervals were: $100 \%, 85 \%, 91 \%$ for praziquantel; $92 \%, 80 \%, 87 \%$ for oxamniquine; and $95 \%, 75 \%$, $86 \%$ for the combination, according to the KatoKatz method. Taken into account the findings of the MIF concentration in addition to the re sults by Kato-Katz, and embraceing the whole twelve months of parasitological follow-up, cure rates of $81.8 \%, 81.2 \%$ and $67.6 \%$ were achieved with praziquantel, oxamniquine and the combination respectively, as shown in Table III. The relative frequencies of parasitological cures did not differ statistically between the groups.

\section{TABLE III}

Overall results of the parasitological examinations by Kato-Katz and MIF methods, during the entire 12-month follow-up.

\begin{tabular}{l|c|c|c}
\hline Drug groups & Praziquantel & Oxamniquine & OXM \& PZQ \\
\hline Negative cases & 18 & 26 & 23 \\
Positive cases* & 4 & 6 & 11 \\
Cure rates & $81.8 \%$ & $81.2 \%$ & $67.6 \%$ \\
\hline
\end{tabular}

* One patient in the oxamniquine and one in the combination group was found positive by the MIF concentration only.

In those patients still excreting eggs after treatment, considerable reductions in egg counts were observed. They also did not differ significantly between the three groups, and the number of remaining positive cases was too small to allow statistical comparison of persisting excretion of $\mathbf{S}$. mansoni. It is visualized in Figure 1, however, that the reincrease of egg excretion in non-cured patients appears to be steeper in those treated with oxamniquine than in those who received praziquantel.

\section{DISCUSSION}

Our results confirm the similar efficacy of praziquantel and oxamniquine when used in conventional dosages for treating $\mathbf{S}$. mansoni infection, as already demonstrated in double-blind comparative trials carried out in Brazil ${ }^{7},{ }^{14}, 22.34$. In addition, it has been disclosed that a lowdose combination of both drugs is effective, with $67.6 \%$ of patients no longer excreting ova after the treatment and an average reduction of egg counts of $88.7 \%$ in those patients in whom no

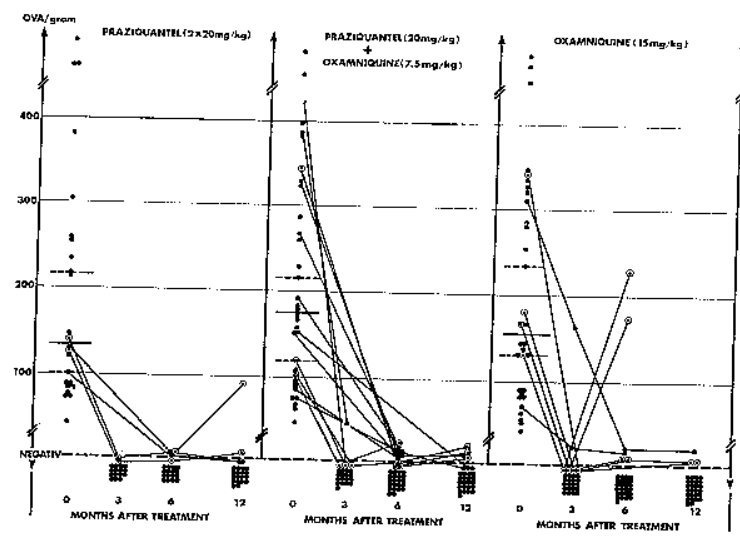

Fig. 1 - S. MANSONI OVA EXCRETION IN INDIVIDUAL PATIENTS (points indicate the EPG of each case, those negative at the first follow-up but positive on subsequent examinations are denoted by open circles. Medians and $95 \%$ confidence limits prior to therapy are indicated by horizontal bars. Followup examinations positive by MIF concentration only are not quantified).

complete parasitological cure was accomplished.

A similar dosage to the one we used in this trial has previously shown to be advantageous in a dose-finding study conducted in $\mathrm{Malawi}^{43}$. The children treated in this country had 2 to 4 times higher egg counts prior to treatment, and many were concomitantly infected with $\mathbf{S}$. haematobium. In that study, the reduction of ova excretion three months after therapy was marginally lower using $7.5 \mathrm{mg} / \mathrm{kg}$ oxamniquine plus $15 \mathrm{mg} / \mathrm{kg}$ praziquantel, as compared to the group treated with $10 \mathrm{mg} / \mathrm{kg}$ oxamniquine plus $20 \mathrm{mg} / \mathrm{kg}$ praziquantel ( $93 \%$ vs. $97 \%$ ). Six months after treatment little difference was apparent between the two dosage schemes (95\% vs. $96 \%$ ).

In our trial the post-treatment decrease of S. mansoni ova excretion and cure rate seemed more favourable for the group treated with praziquantel alone, however, the initial egg count was slightly lower than in the two remaining groups. In this connection, a statistically significant difference in the reduction of the mean numbers of eggs per gram of faeces after treatment with praziquantel in comparison to oxamniquine has been reported in a much larger sized sample ${ }^{17}$. A reincrease in egg counts upon reexamination six and twelve months after treatment was noted in two to three patients in each group in whom the counts had fallen to nought or 10 eggs per 
ZWINGENBERGER, K.; NOGUEIRA QUEIROZ; J. A.; POGGENSEE, U.; ALENCAR. J. E.; VALDEGUNAS, J.; ESMERALDA, F. \& FELDMEIER, H. - Efficacy of oxamniquine, praziquantel and a combination of both drugs in schistosomiasis mansoni in Brazil. Rev. Inst. Med. trop. Sáo Paưlo, 29:305-311, 1987.

gram 3 months post-therapy. This finding was most pronounced on the 6th. month after treatment in the oxamniquine group. Actually, in two cases treated with this drug the egg counts reached pre-therapeutical levels. This could be due to a diminished susceptibility of $\mathbf{S}$. mansoni strains to this drug but the possibility of reinfection or relapse cannot be ruled out either. In regard to this, the assessment of oxamniquine efficacy by the quantitative oogram technique has been indicative of persistance of egg production four months on after treatment ${ }^{12}$.

In conclusion, a single dose administration of oxamniquine $15 \mathrm{mg} / \mathrm{kg}$ or praziquantel $40 \mathrm{mg} /$ $\mathrm{kg}$ or a half-dose combination of both drugs proved to be similarly effective in schistosomiasis mansoni in Brazil, as analogous cure rates and reductions of egg excretion in non-cured cases were achieved. It remains speculative whether this combination will prevent further development of oxamniquine resistance, which could turn into a serious hazard for schistosomiasis control in Brazil. Finally it should be emphasized that these are only preliminary results not to be extrapolated to large scale therapy.

\section{RESUMO}

\section{Eficácia da oxamniquine, do praziquantel e da combinação de ambas as drogas na esquistossomose mansônica no Brasil.}

Conduziu-se um ensaio clínico para comparar a eficácia de uma combinação em baixas doses de oxamniquine $(7,5 \mathrm{mg} / \mathrm{kg})$ mais praziquantel $(20 \mathrm{mg} / \mathrm{kg}) \mathrm{com}$ ambas as drogas - oxamniquine $(15 \mathrm{mg} / \mathrm{kg})$ e praziquantel $(40 \mathrm{mg} / \mathrm{kg})-$ empregadas isoladamente, no tratamento da esquistossomose mansônica em uma área endêmica do nordeste brasileiro.

Os medicamentos foram administrados, aleatoriamente, por via oral, a 91 pacientes. Seis e doze meses depois do tratamento $89 \%$ dos admitidos no ensaio foram reexaminados segundo os métodos de Kato-Katz (dez lâminas) e MIF (um grama de fezes).

Os índices de cura alcançados, representando a ausência de ovos nas fezes em todos os controles durante o acompanhamento parasitoló- gico individualizado dos pacientes, foram de $81,8 \%, 81,2 \%$ e $67,6 \%$ com, respectivamente, o praziquantel, a oxamniquine e a combinação. A redução do número de ovos eliminado por grama de fezes nos casos não curados, variou de $93,8-96,8 \%$ com o praziquantel, $32,5-97 \%$ com a oxamniquine e 76,9-99,5\% com a combinaçầo.

Concluiu-se que os três regimes terapêuti$\cos$, nas doses utilizadas, dão resultados similares e satisfatórios no tratamento da esquistossomose mansônica não complicada, no Brasil.

\section{ACKNOWLEDGEMENTS}

The collaboration of SUCAM field microscopists, Romulo M. do Nascimento and Maria A. de $\mathbf{S}$. Bento is greatly appreciated. Technical assistance was also provided by E. Adusu, J. Weber-Adusu and $\mathrm{K}$. Störzel. Prof. Naidu, Universidade Federal do Ceará, Fortaleza, gave valuable advises.

\section{REFERENCES}

1. ANDREWS, P. - A summary of the efficacy of praziquantel against schistosome in animal experiments and notes on its mode of action. Drug Res., 31 (Suppl. I): 538-541. 1981 .

2. ARAUJO, N.; KATZ, N.; DIAS, E. P. \& SOUZA, C. P. de P. - Susceptibility to chemotherapeutic agents of strains of $\mathbf{S}$. mansoni isolated from treated and untreated patients. Amer. J. trop. Med. Hyg., 29: 890-895, 1980.

3. BASSILY, S.; FARID, Z.; HIGASHI, G. I. \& WATTEN, R. H. - Treatment of complicated schistosomiasis mansoni with oxamniquine. Amer. J. trop. Med. Hyg., 27: 1284-1286, 1978.

4. BERTI, J. J. \& SCHMIDT-DOMMERQUE, F. - Ensayo terapéutico con praziquanttel en casos de schistosomiasis mansoni resistentes al oxamniquine. Trib. med. (Venezuela), 54: 6-7, 1981.

5. BINA, J. C. \& SPINOLA, A. - Convulsão associada ao uso de oxamniquine. Relato de um caso. Rev. Soc. bras. Med. trop., 10: 221-223, 1976.

6. BLAGG, W.; SCHLOEGEL, E. L.; MANSOUR, N. S. \& KHALAF, G. I. - A new concentration technique for demonstration of protozoa and helminth eggs in feces. Amer. J. trop. Med. Hyg., 4: 23-28, 1955.

7. BRANCHINI, M. L. M.; PEDRO, R. de J.; DIAS, L. C. de S. \& DEBERALDINI, E. R. - Double-blind clinical 
ZWINGENBERGER, K.; NOGUEIRA QUEIROZ, J. A.; POGGENSEE, U.; ALENCAR, J. E.: VALDEGUNAS, J.; ESMERALDA F. \& FELDMEIER, H. - Efficacy of oxamniquine, praziquantel and a combination of both drugs in schistosomiasis mansoni in Brazil. Rev. Inst. Med. trop. São Paulo, 29:305-311, 1987.

trial comparing praziquantel with oxamniquine in the treatment of patients with schistosomiasis mansoni. Rev. Inst. Med. trop. S. Paulo, 24: 315-321, 1982.

8. BRUCE, J. - Tratamento da esquistossomose mansonnica experimental de primatas com a associação de oxamniquine e praziquantel. (Mesa-redonda no XXI CONGRES SO DA SOCIEDADE BRASILEIRA DE MEDICINA TROPICAL, SÂO PAULO, 1985).

9. CAMARGO, S. - Tratamento com praziquantel de portadores de esquistossomose, em área endèmica, com persistência de positividade após sucessivas administraçóes de oxamniquine. Rev. Inst. Med. trop. S. Paulo, 24: 180-187, 1982

10. CAMPOS, R.; PINTO, P. L. S.; SANT'ANA, E. J.; MOREIRA, A. A. B.; AMATO NETO, V.; PADILHA, L. A. A.; LEVAI, E. V. \& CATALANO, C. M. - A associaçào de oxamniquine e praziquantel no tratamento da esquistossomose mansônica. In: CONGRESSO DA SOCIEDADE BRASILEIRA DE MEDICINA TROPICAL, 21., Sāo Paulo, 1985. Programa e resumos. Sảo Paulo, CLR Balieiro Editores, 1985. p. 51. res. n: 41 .

11. COUTINHo, A.; DOMINGUUes, A. L. C.; NEVES, J. \& ALMEIDA, S. T. - Treatment of hepatosplenic schistosomiasis mansoni with praziquantel. Drug Res., 33: 787-791, 1983.

12. da CUNHA, A. S. - A avaliação terapéutica da oxamniquine na esquistossomose mansoni humana pelo método do oograma por biópsia de mucosa retal. Rev. Inst. Med. trop. S. Paulo, 24: 88-94, 1982.

13. da SILVA, L. C.; SETTE, C.; CHRISTO, C. H.; SAÉZ-AL QUEZAR, A.; CARNEIRO, C. R. W.; LACET, C. M.; OHTSUKI, N. \& RAIA, S. - Praziquantel in the treatment of the hepatosplenic form of schistosomiasis mansoni. Drug Res., 31: 601-603, 1981 .

14. da SILVA, L. C.; ZEITUNE, J. M. R.; ROSA-EID, L. M. F.; LIMA, D. M. C.; ANTONELLI, R. H.; CHRISTO, C. H.; SAEZ-ALQUEZAR, A. \& CARBONI, A. de C. - Treatment of patients with schistosomiasis mansoni: a double blind clinical trial comparing praziquantel with oxamniquine. Rev. Inst. Med. trop. S. Paulo, 28: 174-180, 1986.

15. de CARVALHO; S. A.; AMATO NETO, V.; GRYSCHEK R. C. B.; SHIKANAIYASUDA, M. A. \& SHIROMA, M. - Efeitos colaterais e eficácia da associaçâo oxamniqui ne/praziquantel no tratamento da infecção humana pelo Schistosoma mansoni. Rev. Soc. bras. Med.. trop., 19 (Supl.): 57, 1986.

16. de CARVALHO, S. A.; SHIKANAI-YASUDA; M. A.; AMATO NETO, V.; SHIROMA, M. \& LUCAS, F. J. C. - Neurotoxicidade do oxamniquine no tratamento da infecçâo humana pelo Schistosoma mansoni. Rev. Inst. Med. trop. S. Paulo, 27: 132-142, 1985.

17. de REZENDE, G. L - Survey on the clinical trial results achieved in Brazil comparing praziquantel and oxamni- quine in the treatment of mansoni schistosomiasis. Rev. Inst. Med. trop. S. Paulo, 27: 328-336, 1985.

18. DIẠS, E. P.; KATZ, N. \& ARAÚJO, N. - Associação de drogas esquistossomose na terapéutica experimental de camundongos. In: CONGRESSO DA SOCIEDADE BRASILEIRA DE MEDICINA TROPICAL 16., Natal, 1980. Resumo. Natal, 1980. res. n. 167.

19. DIAS, L. C. de S.; PEDRO, R. de J.; RIGO, E.; GOTO, M.M.F. \& MAFRA, G. L. - Linhagem humana de Schistosoma mansoni resistente a esquistossomicidas. Rev. Saúde públ. (S. Paulo), 12: 110, 1978.

20. DIAS, L. C. de S.; PEDRO, R. de J. \& DEBERALDINI, E. R. - Use of praziquantel in patients with schistosomiasis mansoni previously treated with oxamniquine and/ or hycanthone: resistance of $\mathbf{S}$. mansoni to schistosomicidal agents. Trans. roy: Soc. trop. Med. Hyg., 76: 652-659, 1982.

21. DIETZE, R. \& PRA'TA, A. - Eñécícia da associaçāo oxamniquine e praziquantel na cura da esquistossomose mansônica. Rev. Soc. bras. Med. trop., 19: 247-249, 1986.

22. EMANUEL, A. \& PRATA, A. - Comparaçáo entre prazi quantel e oxamniquine no tratamento da esquistossomose mansoni. Rev. Soc. bras. Med. trop., 16: $90-93,1983$.

23. FARID, Z.; HIGASHI, G. I.; BASSILY, S.; TRABOLSI, E. \& WATTEN, H. - Treatment of advanced hepatosplenic schistosomiasis with oxamniquine. Trans. roy. Soc. trop. Med. Hyg., 74: 400-401, 1980.

24. FROHBERG, H. \& SCHULZE-SCHENCKING, M. - Toxicological profile of praziquantel, a new drug against cestode and schistosome infections, as compared to some other schistosomicides. Drug Res., 31: 555-565, 1981.

25. FROHBERG, H. - Results of toxicological studies on praziquantel. Drug Res., 34: 1137-1144, 1984.

26. GÖNNERT, R. \& ANDREWS, P. - Praziquantel a new broad spectrum antischistosomal agent. Z. Parasitenk 52: 129-150, 1977.

27. GROLL, E. - Praziquantel for cestode infection in man. Acta trop. (Basel), 37: 293, 296, 1980.

28. GUIMARĀES, R. X.; TCHAKERIAN, A.; DIAS, L. C. de S.; de ALMEIDA, F. M. R.; VILELA, M. P.; CABEÇA, M. \& TAKEDA,A.K.-Resisténcia ao hycanthone examniquine em doentes com esquistossomose forma clinica hepatintestinal. Rev. Ass. méd. bras., 25: 48-50, 1979.

29. HIRSCH, R.; DIAS, E. P.; OLIVEIRA, T. F. R. \& KATZ, N. - Associação de drogas no tratamento da esquistossomose mansoni experimental. Rev. Soc. bras. Med. trop, 19 (Supl.): 59, 1988 .

30. KATZ, N. - Experiência com quimioterapia em grande escala no controle da esquistossomose no Brasil. Rev. Inst. Med. trop. S. Paulo, 22: 40-51, 1980. 
ZWINGENBERGER, K.; NOGUEIRA QUEIROZ, J. A.; POGGENSEE, U. ALENCAR, J. E.; VALDEGUNAS, J.; ESMERALDA, F. \& FELDMEIER, H. - Efficacy of oxamniquine, praziquantel and a combination of both drugs in schistosomiasis maneoni in Brazil. Rev. Inst. Med. trop. São Paulo, 29:305-311, 1987.

31. KATZ, N.; CHAVES, A. \& PELLEGRINo, J. - A simple device for quantitative thick smear technique in schistosomiasis mansoni. Rev. Inst. Med. trop. S. Paulo, 14: $397-400,1972$.

32. KATZ, N.; DIAS, E. P.; ARAÚJO, M. \& SOUZA, C. P - Estudo de uma cepa humana de Schistosoma mansoni resistente a agentes esquistossomicidas. Rev. Soc. bras. Med. trop., 7: 381-387, 1973

33. KATZ, N.; GRINBAUM, E.; CHAVES, A.; ZICKER, F. \& PELLEGRINO, J. - Clinical trials with oxamniquine, by oral route, in schistosomiasis mansoni. Rev. Inst. Med. trop. S. Paulo, 18: 371-377, 1976.

34. KATZ, N. \& ROCHA, S. - Double-blind clinical trial comparing praziquantel with oxamniquine in schistosomiasis mansoni. Rev. Inst. Med. trop. S. Paulo, 24: 310-314, 1982.

35. KAYE, B. \& WOOLHOUSE, N. M. - The metabolism of oxamniquine - a new schistosomicide. Ann. trop. Med. Parasit., 70: 323-328, 1976

36. KEYSTONE, J. S. - Seizures and electroencephalograph changes associated with oxamniquine theraphy. Amer. J. trop. Med. Hyg., 27: 360-362, 1978.

37. KRAJDEN, S.; KEYSTONE, J. S. \& GLENN, C. - Safety and toxicity of oxamniquine in the treatment of Schistosoma mansoni infections, with particular reference to electroencephalographic abnormalities. Amer. J. trop. Med. Hyg., 32: 1344-1346, 1983.

38. LEOPOLD, G.; UNGETHŨM, W., GROLL, E.; DIEKMANN, H. W.; NOWAK, H. \& WEGNER, D. H. G. Clinical pharmacology in-normal volunteers of praziquantel, a new drug against schistosomes and cestodes. Europ. J. clin. Pharmacol., 14: 281-291, 1978.

39. OMER, A. H. S. - Oxamniquine for treating Schistosoma mansoni infection in Sudan. Brit. med. J., 2: 163-165, 1978

40. PEDRO, R. de J.; DIAS, L. C. de S.; AMATO NETO, V \&CARVALHO, S. A. de - Observations on the treatment of mansoni schistosomiasis with oxamniquine. Rev. bras. Pesq. méd. biol., 12: 207-211, 1979.

41. PEDRO, R. de J.; DIAS, L. C. de S.; AMATO NETO, V. \& CARVALHO, S. A. de - Observations on the treatment of schistosomiasis mansoni with oxamniquine: efficacy in children and in persistent salmonellosis; resistance of a strain of $\mathbf{S}$. mansoni; hepatic toxicity and neurological side effects. Rev. Inst. Med. trop. S. Paulo, 22 (Supl. 4) $32-36,1980$
42. PRATA, A.; LAURIA, L.; FIGUEIREDO, J. F. M. \& SENNA, P. G. de - Tratamento da esquistossomose pela oxamniquine em dose única, pela via oral. Rev. Soc. bras. Med. trop., 10: 127-136, 1975.

43. PUGH, R. N. H. \& TEEDSDALE, C. H. - Synergy of concurrent low dose oxamniquine and prazinquantel in the schistosomiasis. Brit. med. J., 287: 877-878, 1983.

44. SHAW, J. R. \& BRAMMER, K. W. - The treatment of experimental schistosomiasis with combination of oxam niquine and praziquantel. Trans, roy. Soc: trop. Med. Hyg., 77: 39-40, 1983

45. SLEXGH, A.; MOTT, K. E.; FRANÇA SILVA, J. T.; MUNIZ, T. M.; MOTA, E. A.; BARRETO, M. L.; HOFF, R.; MAGUIRE, J. H.; LEHMAN, J. S. \& SHERLOCK, I. A three year follow-up of chemotherapy with oxamniquine in a brazilian community with endemic schistosomiasis mansoni. Trans. roy. Soc. trop. Med. Hyg., 75: 234-238, 1981.

46. SLEIGH, A.; HOFF, R.; MOTT, K. E.; BARRETO, M.; PAIVA, T. M. de; PEDROSA, J. de S. \& SHERLOCK, I. - Comparison of filt filtration staining (Bell) and thick smear (Kato) for the detection and quantitation of S. mansoni eggs in faeces. Trans. roy. Soc. trop. Med. Hyg., 76: $403-406,1982$.

47. STORKVIS, H.; BAUER, A. C. G.; STUIVER, P. C.; MAL COLM, A. D. \& OVERBOSCH, D. - Seizures associated with oxamniquine therapy. Amer. J. trop. Med. Hyg., 35: 330-331, 1986

48. WARREN, K. S. \& MAHMOUD, A. A. F. - Targeted mass treatment: a new approach to the control of schistosomiasis. Trans. Ass. Amer. Phycns., 89: 195-204, 1976.

49. WEBBE, G. \& JAMES, C. - A comparison of the susceptibility to praziquantel of S. haematobium, S. Japonicum, S. mansoni, S. intercalatum and $\mathbf{S}$. matthei in hamsters. Z. Parasitenk., 52: 169-177 1977.

50. WEGNER, D. H. G. - The profile of the trematodicidal compound praziquantel. Drug Res., 34: 1132-1136, 1984.

51. WORLD HEALTH ORGANIZATION - The special program for schistosomiasis control in Brazil. Geneva, 1982. WHO/SCHISTO/83.67.

52. WORLD HEALTH ORGANIZATION - The role of chemotherapy in schistosomiasis control. Geneva, 1985. WHO/SCHISTO $/ 85.70$.

Recebido para publicaçāo em 23/03/87. 